особенностей течения ХОЗЛ на фоне ИБС, что позволит выделить критерии развития и прогноза сочетанной патологии.

Ключевые слова: ХОЗЛ, ИБС, критерии развития, клинико-анамнестические особенности течения.

\title{
CORONARY HEART DISEASE AND CHRONIC OBSTRUCTIVE PULMONARY DISEASE: CLINICAL AND ANAMNESTIC CHARACTERISTICS OF THE DISEASE IN PATIENTS WITH COMORBID PATHOLOGY
}

\section{U.V. Sinko, I.P. Vakaliuk}

\begin{abstract}
Clinicoanamnestic characteristics of the disease were studied in 30 patients with COPD, 30 patients with coronary artery disease and 120 patients with COPD combined with coronary artery disease. The results suggest "mutual aggravation" of current comorbidity, and therefore follow-up studies should be directed at finding clinicoanamnestic features of COPD against the background of coronary artery disease, which will highlight the development of criteria and prognosis of comorbidity.
\end{abstract}

Key words: chronic obstructive pulmonary disease, coronary artery disease, development criteria, clinicoanamnestic features of the course.

National Medical University (Ivano-Frankivsk)

Рецензент - проф. Т.О. Ілащук

Buk. Med. Herald. - 2015. - Vol. 19, № 3 (75). - P. 155-158

Надійшла до редакції 19.05.2015 року

(c) У.В. Синько, І.П. Вакалюк, 2015

УДК 616.33-002.2-036.65-02-085.243.4

\section{Є.Я. Скляров, Махер Мбаркі \\ ОСОБЛИВОСТІ МЕХАНІЗМУ ДІЇ ІНГІБІТОРІВ ПРОТОННОЇ ПОМПИ У ЛІКУВАННІ НПЗП-ГАСТРОПАТІЙ}

Львівський національний медичний університет імені Данила Галицького

\begin{abstract}
Резюме. Проведена оцінка ролі лейкотриєну В4 (LTB4) та простагландину E2 (PgE2) у розвитку НПЗПгастропатій на тлі призначення інгібіторів протонної помпи. Встановлено, що призначення нестероїдних протизапальних препаратів у профілактичній дозі хворим із кардіоваскулярною патологією призводить до пригнічення циклооксигенази, зміщаючи рівновагу між PgE2 та LTB4 на користь останніх із подальшим розвитком НПЗП-гастропатій. Застосування пантопразолу
\end{abstract}

Вступ. Ацетилсаліцилову кислоту (АСК) широко застосовують у лікуванні осіб із кардіоваскулярною патологією для профілактики тромбозів та емболій як основних причин гострих серцево-судинних ускладнень. Здатність АСК знижувати ризик смерті, частоту виникнення ішемічного інсульту та інфаркту міокарда беззаперечно доведена у великих рандомізованих клінічних дослідженнях [6].

Разом 3 тим при прийомі НПЗП можуть уражуватися будь-які відділи травного каналу - від стравоходу до прямої кишки, але найбільш частими та небезпечними виявляються ерозивновиразкові пошкодження гастродуоденальної зони та їх ускладнення (кровотечі, перфорації) $[2,7]$.

На сьогодні переглянуті погляди стосовно безпечності низьких доз АСК, які найчастіше використовують для профілактики кардіоваскулярних захворювань. Так, застосування кардіо(C) С.Я. Скляров, Махер Мбаркі, 2015 158 призводило до зменшення ерозивно-виразкових уражень гастродуоденальної зони на тлі прийому ацетилсаліцилової кислоти (АСК). Крім того, призначення пантопразолу призводило до суттєвого зниження показників LTB4 без достовірних змін вмісту PgE2, що необхідно враховувати для подальшої корекції лікування таких осіб.

Ключові слова: НПЗП-гастропатія, пантопразол, простагландин Е2, лейкотриєн В4.

протективних доз АСК підвищує ризик розвитку пептичних виразок: у дозі 75 мг у 2,3 раза, 150 мг - у 3,2 раза, 300 мг - у 3,9 раза [7]. Важливо, що при одночасному застосуванні низькодозових препаратів АСК та інших НПЗП спостерігається ефект сумації, який вдвічі підвищує можливість утворення перфорацій і кровотеч [7]. Застосування вкритого кишковорозчинною оболонкою або буферизованого АСК не довело будь-якої переваги відносно зниження частоти виникнення гастроінтестинальних ускладнень [10].

Проявами уражень шлунка та ДПК при вживанні АСК є поява гострих, часто множинних, ерозій та/або виразок, відсутність симптомів чи незначна їх вираженість. У 70 \% НПЗП-гастродуоденопатії мають безсимптомний перебіг, часто спостерігаються кровотечі, перфорації. Основними ознаками НПЗП-гастропатії $\epsilon$ ураження переважно антрального відділу шлунка, відсут- 
ність локального запалення та гістологічних маркерів гастриту, фовеолярна гіперплазія слизової оболонки шлунка та порівняно швидкий регрес після відміни НПЗП [3].

При ендоскопії у 40-50 \% пацієнтів, що тривало приймають НПЗП, виявляють ерозії та виразки. Поодинокі та множинні ерозії знаходять у 50 \% осіб, а виразки, частіше шлункової локалізації - у 25 \% 3 них [2]. Пацієнти літнього віку більш схильні до появи такої гастропатії, причому у віці більше 65 років ризик виникнення симптоматичних чи ускладнених виразок у шлунку або в ДПК зростає до $87,1 \%[6,11]$.

Розвиток НПЗП-гастропатій зумовлений як прямою дією АСК на епітеліоцити, так і здатністю НПЗП модифікувати фактори агресії та захисту слизової оболонки гастродуоденальної зони. НПЗП, і зокрема АСК, є слабкими органічними кислотами, які легко проникають через фосфоліпідну мембрану в цитоплазму епітеліальних клітин і викликають локальні пошкодження - від точкових ерозій до виразок [2].

Функцію захисту слизової оболонки шлунка та ДПК виконують простагландини групи Е2 та I2 через пригнічення продукції Н-іонів та пепсиногену, зниження ацидопептичної активності шлункового соку та одночасно стимулюють процеси клітинної регенерації [8]. Систематичний прийом НПЗП призводить до гіперсекреції шлункового соку, збільшенню його агресивності та до пригнічення продукції бікарбонатів і слизу $[5,9]$. У механізмі розвитку деструктивних процесів у слизовій оболонці шлунка та ДПК внаслідок прийому НПЗП важлива роль відводиться взаємодії простагландину E2 (PgE2) та лейкотриєнів B4 (LTB4) [12]. Основним субстратом для синтезу Pg (E2, I2, F2) та їх нестабільних метаболітів $\epsilon$ арахідонова кислота. Циклооксигеназа каталізує дві ключові реакції арахідонової кислоти - циклооксигеназний та ліпооксигеназний. У першому випадку утворюються простагланидини, простациклін і тромбоксан, а в другому - лейкотриєни, ліпоксини, гіпоксиліни (А3, В3) [1]. Призначення НПЗП призводить до гальмування ЦОГ-1 залежного синтезу Pg на тлі достатньої продукції LTB4, який сприяє запаленню та токсичному пошкодженню покривного епітелію травного каналу [6].

Мета дослідження. Оцінити роль LTB4 та PgE2 у розвитку НПЗП-гастропатій на тлі призначення інгібіторів протонної помпи (ІПП).

Матеріал і методи. Обстежено 70 пацієнтів із НПЗП-гастропатією у поєднанні з IXC, стабільною стенокардією. У відповідності з метою дослідження пацієнтів розподілено на дві групи. До першої групи увійшли 37 пацієнтів, які 3 профілактичною метою тривалий час приймали АСК у дозі 75 мг на добу. До другої групи увійшли 33 пацієнти з відповідною патологією, яким для запобігання розвитку ускладнень на тлі прийому АСК призначали пантопразол у дозі 40 мг на добу.

Серед пацієнтів першої групи - 22 (59,5 \%) чоловіки і 15 (40,5 \%) жінок. Серед пацієнтів дру- гої групи -19 (57,6 \%) чоловіків та 14 (42,4%) жінок. Вік пацієнтів коливався від 40 до 87 років

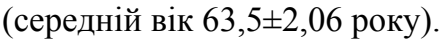

До контрольної групи увійшло 10 практично здорових осіб, віком від 18 до 28 років, без клінічних ознак захворювання та видимих патологічних змін слизової оболонки під час фіброгастродуоденоскопічного обстеження.

Усім пацієнтам проводили загальноклінічні обстеження, лабораторні дослідження, фіброгастродуоденоскопію (ФГДС), визначали вміст ендогенного простагландину Е2 та лейкотриєну В4.

Для верифікації гастродуоденальної патології використовували ФГДС за допомогою апарата Pentax EC-34 JA (Японія) з біопсією слизової оболонки астрального та фундального відділу шлунка. Під час ФГДС проводили візуальну оцінку слизової оболонки гастродуоденальної зони. Звертали увагу на наявність гіперемії, набряку, ерозивно-виразкових дефектів, рубцевої деформації цибулини дванадцятипалої кишки, тонус кардіального сфінктера і воротаря, наявність гастроезофагеального та дуоденогастрального рефлюксів.

Вміст ендогенного PgE2 у сироватці крові досліджували імуноферментним методом за допомогою набору реагентів PGE2 Immunoassay R\&D Systems 3 побудовою контрольного калібрувального графіка та порівняння отриманих величин.

Концентрацію LTB4 B4 у плазмі крові визначали імуноферментним методом за допомогою тест-системи LTB4 ELISA test kit (Neogen corporation, USA) 3 наступною побудовою калібрувального графіка і визначенням концентрації зразків зі стандартної кривої.

Статистична обробка отриманих результатів виконана на персональному комп'ютері з використанням пакетів ліцензійних програм "Microsoft Excel 2007" (Microsoft), "Statistica ${ }^{\circledR}$ 6.0" (StatSoft Inc., США). Оцінювали середнє значення (M) та стандартну похибку середнього (m). Достовірність змін показників оцінювали з використанням парного критерію Стьюдента. Розбіжності вважали достовірними при $\mathrm{p}<0,05$. Для дослідження взаємозв'язку нормально розподілених кількісних ознак використовували кореляційний аналіз Пірсона. Порівняння незалежних груп проводилося за критеріями Манн-Уітні.

Результати дослідження та їх обговорення. Під час госпіталізації при ендоскопічному дослідженні в пацієнтів першої групи виразки шлунка та ДПК знаходили у 17,1 \% та 14,3 \% випадків; ерозивні дефекти, часто множинного характеру, виявляли в тілі шлунка в $63,0 \%$ і в ДПК - у 43,0 \% випадків відповідно.

Серед пацієнтів 2-ї групи, які окрім АСК додатково приймали пантопразол, виразки шлунка та ДПК знаходили у 7,4 \% та 3,7 \% випадків відповідно. На тлі лікування пантопразолом кількість ерозивних дефектів в тілі шлунка знаходили в 51,8 \% та в ДПК - у 29,6 \% випадків. 


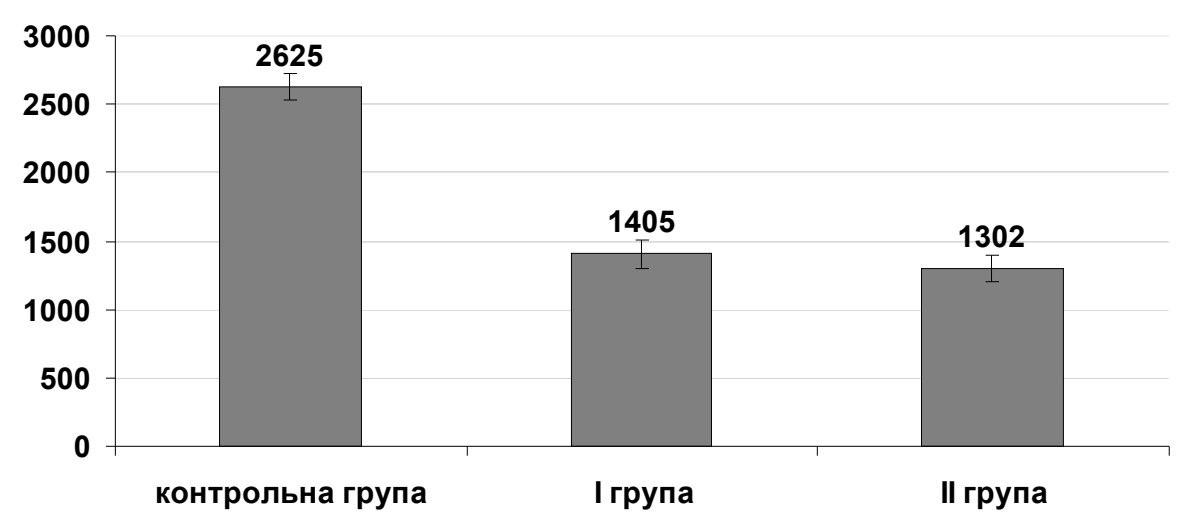

Рис. 1. Рівень PgE2 у практично здорових осіб та пацієнтів із НПЗП-гастропатіями

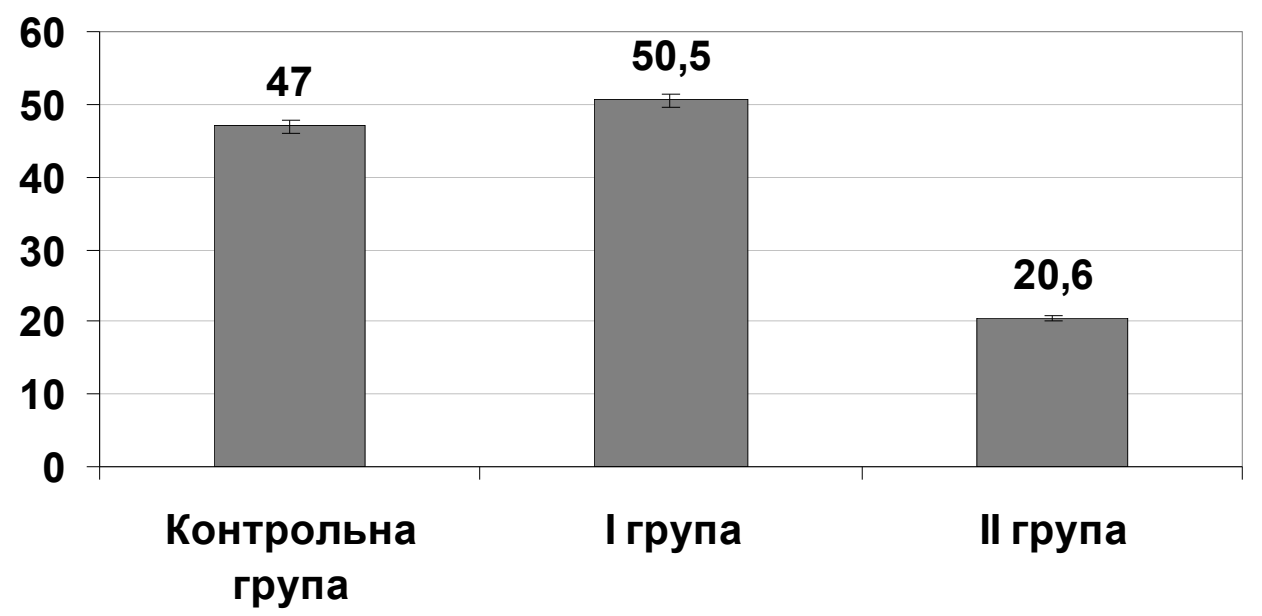

Рис. 2. Рівень LTB4 у практично здорових осіб та пацієнтів з НПЗП-гастропатіями

При порівнянні показників ендогенного простагландину в пацієнтів з НПЗП-гастропатією та в контрольній групі практично здорових осіб відмічалося суттєве зниження концентрації PgE2 на тлі прийому АСК (р<0,01) (рис. 1).

$\mathrm{У}$ той же час курсовий прийом пантопразолу не призвів до будь-яких суттєвих змін величин PgE2 (p>0,05) у пацієнтів 2-ї групи (рис. 1).

Рівень LTB4 вірогідно не відрізнявся у практично здорових осіб та в пацієнтів 1-ї групи 3 НПЗП-гастропатією (p>0,05) (рис. 2).

Разом 3 тим, при курсовому призначенні пантопразолу пацієнтам 2-ї групи 3 НПЗПгастропатіями відбувалося достовірне зниження вмісту LTB4 (p<0,01) (рис. 2).

Лейкотриєн В4 та простагландин Е2 є найбільш вагомими факторами, які залучені у процеси агресії та захисту слизової оболонки шлунка та дванадцятипалої кишки. У фізіологічних умовах існує рівновага між продукцією цих похідних арахідонової кислоти.

Призначення нестероїдних протизапальних препаратів пацієнтам із кардіоваскулярною патологією для профілактики тромбозів та емболій призводить до пригнічення циклооксигенази, зміщаючи рівновагу між PgE2 та LTB4 на користь останніх із подальшим розвитком НПЗПгастропатій.

Методом вибору профілактики ерозивновиразкових уражень гастродуоденальної зони $\epsilon$ застосування ІПП. У процесі лікування пацієнтів iз НПЗП-гастропатіями встановлено значне зменшення ерозій та виразок після курсового призначення пантопразолу. Розгляд співвідношень між величинами LTB4 та PgE2 показав, що під впливом пантопразолу переважно зменшується рівень LTB4, у той час як вміст PgE2 залишається достатньо низьким.

Такі особливості механізму дії ІПП необхідно брати до уваги при лікуванні пацієнтів з IXC, які змушені тривалий час приймати нестероїдні протизапальні препарати.

\section{Висновки}

1. За даними фіброгастродуоденоскопії курсове призначення пантопразолу призводило до зменшення ерозивно-виразкових уражень гастродуоденальної зони на тлі прийому ацетилсаліцилової кислоти. У пацієнтів з нестероїдними - гастропатіями відбувалося достовірне зменшення 
вмісту ендогенного простагландину Е2 та тлі високих значень лейкотриєну В4.

3. Призначення пантопразолу при нестероїдних-гастропатіях призводило до суттєвого зниження показників LTB4 без значущих змін вмісту PgE2 , що необхідно враховувати для подальшої корекції лікувальної тактики ведення таких хворих.

Перспективи подальших досліджень. Отримані дані співвідношення PgE2 і LTB4 при НПЗПгастропатіях обгрунтовують необхідність подальших досліджень даних ейкозаноїдів із метою корекції лікувальної тактики та профілактики.

\section{Література}

1. Вахрушев Я.М. Энтеропатия, индуцированная нестероидными противовоспалительными препаратами (патогенез, диагностика, лечение) / Я.М. Вахрушев, Е.А. Загребина // Терапевт. арх. - 2012. - № 5. C. 74-79.

2. Карасева Г.А. НПВП-индуцированная гастропатия: от понимания механизмов развития к разработке стратегии профилактики и лечения / Г.А. Карасева // Мед. новости. -2012 . - № 8. - С. 21-26.

3. Свінціцький А.С. Гастропатії, зумовлені нестероїдними протизапальними препаратами: сучасний погляд на проблему / А.С. Свінціцький // Нов. мед. и фармации. Гастроэнтерология. Тематический номер. - 2008. C. 8-10.

4. Свінціцький А.С. Роль фізіологічних медіаторів в адаптивних процесах слизової оболонки шлунка / А.С. Свінціцький, А.В. Антоненко, А.Б. Гладчук // Сучас. гастроентерол. - 2012. - № 2. - С. 95-98.
5. Степанов Ю.М. Вивчення вмісту eNOS та iNOS у слизовій оболонці гастродуоденальної зони у хворих на НПЗП-гастропатії до та після лікування / Ю.М. Степанов, Ю.С. Бреславець // Сучас. гастроентерол. - 2012. - № 1 (63). - С. 32-38

6. Стефанюк М.Ф. Гастропатія, асоційована $з$ прийомом ацетилсаліцилової кислоти: місце омепразолу у профілактиці та лікуванні / М.Ф. Стефанюк, Ю.А. Кобірніченко, Н.М. Сидорова // Therapia. - 2011. - № 10. C. $102-105$.

7. Ткач С.М. Современные подходы к профилактике и лечению НПВП-гастропатий / С.М. Ткач // Гастроентерологія. - 2013. - № 4 (50). - С. 95-102.

8. Циммерман Я.С. Этиология, патогенез и лечение язвенной болезни, ассоциированной с Helicobacter pylori-инфекцией: состояние проблемы и перспективы / Я.С. Циммерман // Клин. мед. - 2006. - № 3. - С. 9-19.

9. Шептулин А.А. Современные возможности лечения и профилактики НПВП-индуцированной гастропатии / А.А. Шептулин // Рос. ж. гастроэнтерол., гепатол. и колопроктол. - 2006. - № 1. - С. 15-19.

10. Deny S. Risk of gastrointestinal haemorrhage with long term use of aspirin: meta-analysis / S. Deny, Y.K. Loke // BMJ. - 2000. - Vol. 321. - P. 1183-1187.

11. Helin-Salmivaara A. Frequent prescribing of drugs with potential gastrointestinal toxicity among continuous users of non-steroidal anti-inflammatory drugs / A. HelinSalmivaara, R. Huupponen, A.Virtanen // Eur. J. Clin. Pharmacol. - 2005. - Vol. 61, № 5-6. - P. 425-431.

12. Okazaki M. Gastric mucosal levels of prostaglandins and leukotriens in patients with gastric ulcer after treatment with rabeprazole in comparison to treatment with ranitidine / M. Okazaki, I. Shimizu, M. Ishikawa // The J. of Med. Investigation. - 2007. - Vol. 54. - P. 83-90.

\section{ОСОБЕННОСТИ МЕХАНИЗМА ДЕЙСТВИЯ ИНГИБИТОРОВ ПРОТОННОЙ ПОМПЫ ЛЕЧЕНИЯ НПВП-ГАСТРОПАТИЙ}

\section{Е.Я. Скляров, Махер Мбарки}

Резюме. Проведена оценка роли лейкотриена B4 (LTB4) и простагландина E2 (PgE2) в развитии НПВПгастропатии на фоне назначения ингибиторов протонной помпы. Установлено, что назначение нестероидных противовоспалительных препаратов в профилактической дозе больным с кардиоваскулярной патологией приводит к угнетению циклооксигеназы, смещая равновесие между PgE2 и LTB4 в пользу последних с последующим развитием НПВП-гастропатии. Применение пантопразола приводило к уменьшению эрозивно-язвенных поражений гастродуоденальной зоны на фоне приема ацетилсалициловой кислоты (АСК). Кроме того, назначение пантопразола приводило к существенному снижению показателей LTB4 без достоверных изменений содержания PgE2, что необходимо учитывать для дальнейшей коррекции лечения таких больных.

Ключевые слова: НПВП-гастропатия, пантопразол, простагландин Е2, лейкотриен В4.

\section{MECHANISM OF ACTION OF PROTON PUMP INHIBITORS IN TREATMENT OF NSAID-GASTROPATHY}

\section{Skliarov E.Y., Maher Mbarki}

Abstract. The research was conducted on effect of proton pump inhibitors on levels of leukotriene B4 (LTB4) and prostaglandin E2 (PGE2) in the development of NSAID-gastropathy. It was established that non-steroidal antiinflammatory drugs when given in preventive doses to patients with cardiovascular pathology leads to the oppression of cyclooxygenase and shift in the balance between PGE2 and LTB4 in favor of the latter, leading to the development of NSAID gastropathy. The use of pantoprazole resulted in a reduction of erosive and ulcerative lesions of gastroduodenal zone while taking acetylsalicylic acid. In addition, the administration of pantoprazole resulted in a significant decrease in levels of LTB4 without significant changes in the content of PGE2, which should be considered for further correction of treatment of such patients.

Key words: NSAIDs- gastropathy, pantoprazole, prostaglandin E2, leukotriene B4

Danylo Halytskyi National Medical University (Lviv) 